August 2009

\title{
Acknowledging Intergenerational Moral Responsibility in the Aftermath of Genocide
}

Armen T. Marsoobian

Follow this and additional works at: https://digitalcommons.usf.edu/gsp

\section{Recommended Citation}

Marsoobian, Armen T. (2009) "Acknowledging Intergenerational Moral Responsibility in the Aftermath of Genocide," Genocide Studies and Prevention: An International Journal: Vol. 4: Iss. 2: Article 12.

Available at: https://digitalcommons.usf.edu/gsp/vol4/iss2/12

This Articles is brought to you for free and open access by the Open Access Journals at Digital Commons @ University of South Florida. It has been accepted for inclusion in Genocide Studies and Prevention: An International Journal by an authorized editor of Digital Commons @ University of South Florida. For more information, please contact digitalcommons@usf.edu. 


\title{
Acknowledging Intergenerational Moral Responsibility in the Aftermath of Genocide ${ }^{1}$
}

\author{
Armen T. Marsoobian \\ Department of Philosophy, Southern Connecticut State University
}

\begin{abstract}
This article argues for the claim that we are morally responsible (in the qualified sense proposed in the article) for the crimes of our ancestors if our ancestors, as a collectivity, were part of a community for whose sake and in whose name crimes were committed that meet the definition of the crime of genocide. This claim of "vicarious intergenerational moral responsibility" is supported by two arguments. The first counters the claim that one cannot have responsibilities for events in the past by arguing that this claim oversimplifies one's relationship to one's past and the collectivities in which people live. Such collectivities, both ethnic and religious, have identities across time; identification with these collectivities involves accepting certain moral obligations. The second argument is based on the following premise: the political, social, cultural, and educational institutions that mark all large collectivities, such as nations, provide a degree of moral reliability that is necessary for individuals to carry out their legitimate interests. We count on such institutions to exemplify the values that allow individuals to flourish in their life activities. These institutions are by their very nature intergenerational. The moral reliability of such institutions thus requires that we endeavor to acknowledge and repair the damage caused by the failure of these institutions in the past. Accordingly, their health engenders a moral obligation on our part. Vicarious intergenerational moral responsibility is a responsibility not to the past per se but to the past as it plays an active role in the present.
\end{abstract}

Keywords: intergenerational moral responsibility, collective responsibility, reconciliation, Armenian Genocide, Turkey

The thesis of this essay can be captured by the following question: Are we morally responsible for the crimes of our ancestors? This is a complex question with many components, but one to which I hope to bring clarity in the course of my argument. I will ultimately argue for a qualified affirmative answer to this question in the specific context of the crime of genocide: yes, we are indeed morally responsible for the crimes of our ancestors, if our ancestors, as a collectivity, were part of a community for whose sake and in whose name crimes were committed that meet the definition of the crime of genocide or crimes against humanity. I call this responsibility "vicarious intergenerational moral responsibility." The chief motivation for writing this essay is to answer those who would deny the relevance of addressing injustices of the past. Such critics often argue that the passage of time, changed geopolitical circumstances, and transformed group identities militate against revisiting such old wounds. Even when the wounds are acknowledged, the moral burdens they may engender are not fully recognized, because of strong unexamined assumptions about how moral culpability is assigned. We assume that we should look for individual agents acting in temporally proximate relations of cause and effect. We find it hard to see ourselves

Armen T. Marsoobian, "Acknowledging Intergenerational Moral Responsibility in the Aftermath of Genocide ${ }^{1 . " ~ G e n o c i d e ~ S t u d i e s ~ a n d ~ P r e v e n t i o n ~ 4, ~} 2$ (August 2009): 211-220. (C) 2009 Genocide Studies and Prevention. doi:10.3138/gsp.4.2.211 
in these equations when it comes to past crimes perpetrated by collectivities. We distance ourselves from such collective actions and from the communities from which they arose, regarding them as in some sense alien to us. These assumptions, whether framed in the arguments of critics or implicit in the indifference of the general public, hinder dialogue and reconciliation between the descendants of perpetrators and those of their victims. My essay employs arguments from recent philosophical work on collective and intergenerational moral responsibility to respond to these concerns and to highlight the problematic nature of these assumptions.

Let me first provide some provisional definitions of the terms employed in addressing the question of whether we are morally responsible for the crimes of our ancestors. First, what do I mean by "ancestors"? What sorts of ancestors am I referring to? We typically think of an ancestor as a person from whom one is descended, often more distant than one's grandparents. The Latin root of the word has the broader meaning "to go before," and I adopt this broader meaning. One's ancestors are the ethnic and/or religious community from whose members one is descended. In most instances there is a genealogical connection with one's ancestors, though the connection could also be through adoption or full assimilation. Accordingly, I refer to "ancestors" and "descendants" not as individuals but as collectivities; a collectivity may have many members who are blood relatives, but it may include others who are members of an ethnic and/or religious community by happenstance or conscious decision. ${ }^{2}$ What I am addressing in this essay are situations in which one dominant ethnic or religious community perpetrated the crime of genocide against another community. The "we" addressed in my question- "Are we morally responsible for the crimes of our ancestors?"-are those descendants who actively identify themselves with an ethnic or religious community some of whose members committed acts of genocide in the past. (More on what I mean by "actively identify" later.) ${ }^{3}$ Given my earlier qualifications, these descendants are not necessarily descendants in any genealogical sense, though they may be. Blameworthiness does not rest on familial ties, though having a close relative who has committed some evil act may impose an added moral burden. Such familial moral burdens do not rise to the level of moral responsibility except in the case of parental responsibilities, both moral and legal, for the misbehaviors of minor children. To reiterate, a descendant, as I use the term here, is one whose ancestors were members of a community, usually an ethnic or religious community, some of whose members committed acts of genocide. ${ }^{4}$ An ethnic German whose parents or grandparents lived in Nazi Germany or a Turk whose grandparents or great grandparents lived in Ottoman Turkey in the period of the Armenian Genocide from 1915 to 1923 would qualify as such a descendant. Again, being (or not being) the grandchild of Talât Pasha or Hermann Goering is not my focus; rather, I will focus here on the current relationship of the grandchild to his or her ethnic community. I will argue that moral assessment, whether self-assessment or the judgment of others, arises out of the nature of one's relationship with one's ethnic group and the social institutions of one's nation. What counts is the relationship between oneself and one's community.

Now that I have defined "ancestors," let us turn to the notion of moral responsibility. The philosophical literature on this topic is vast, and there are many variations on and nuances to the basic meaning of the term "moral responsibility." I adopt Seumas Miller's rudimentary-and, one hopes, uncontroversial-definition. Miller has claimed that on the most basic level, "an agent is morally responsible for an action if the agent was naturally responsible for the action, that is, the agent 
intentionally performed the action and did so for a reason, and the action was morally significant." Failures to act, or acts of omission, fall under this analysis. An action is morally significant in a number of ways. In Miller's words, "The action is intrinsically morally good or bad; the goal or end of the action is morally good or bad; and the (foreseen or unforeseen) consequence of the action is morally good or bad."6 If one considers individual acts, a simple reading of moral responsibility usually involves some notion of causation: I drink heavily at a party, drive my car with my reflexes impaired, and cause an accident that results in significant harm to another person. Moral responsibility and blameworthiness appear to be clear-cut in this case. Yet responsibility does not always result from acts of commission; sometimes it results from acts of omission. I fail to show due diligence in locking up my firearms, my neighbor's children are playing in my house and get access to a gun, the gun accidentally discharges, and a child is fatally injured. Again, moral responsibility appears to be clear-cut in this case. Now extend this reasoning to the case of descendants of genocide perpetrators. A typical response would be that nothing I did or failed to do today, or in my lifetime, caused the deaths of Jews at Auschwitz or of Armenians on the death marches to Der Zor (the desert in Syria where tens of thousands perished). No one can believe in temporally reverse causation. Current events do not cause past events. The past is past; I can do nothing to change it. The case is closed-or so some would claim. The fallacy of such reasoning is obvious, for it misses the point: in accepting moral responsibility in this instance, one is not being asked to change the past. On the contrary, I would claim that in accepting moral responsibility one is being asked to accept responsibility for the present, both for one's own present behavior and for that of one's community. The strategy of reducing moral responsibility to simple individual causation is often employed, whether consciously or not, as a means of avoiding responsibility. More on this point shortly.

Furthermore, I would claim that while causation is often a factor in determining moral responsibility, it is not a necessary condition for it. One can distinguish between backward-looking moral responsibilities and forward-looking claims of moral responsibility. ${ }^{7}$ The drunk-driver scenario is one in which causation-my reckless behaviordetermines the backward-looking claim of moral responsibility. Yet even here, not all harms that I may cause generate claims of moral responsibility; for instance, an unforeseen mechanical failure in my car may lead to an accident in which other people are injured. Forward-looking claims do not involve causation at all. Many people recognize that as members of a community we have a moral responsibility to render assistance when a natural disaster strikes. We cannot cause earthquakes, and so we are not morally responsible for what happens when they strike, but we do have a moral obligation-at least, those of us who do not subscribe to a strong libertarian view-to render assistance to the victims of earthquakes in whatever way we can. Most world religions recognize such moral obligations, which apply both on the individual level and on the communal level. Conceptually, these forward- and backward-looking responsibilities are distinct, but in the real world the two are often found together. For instance, the devastation of Hurricane Katrina in New Orleans was both a man-made and a natural disaster. In that instance, there was plenty of responsibility and blame to go around.

The man-made aspect of the Katrina disaster highlights an important point that is central to my argument that we are morally responsible for the crimes of our ancestors. This is the idea that individual blameworthiness often derives from collective wrongdoing. To understand individual moral responsibility, especially in the case of 
the crime of genocide, we need to make sense of collective agency and the resulting blameworthiness of collectives. A murder that takes place in the context of and as a part of genocide has an added moral feature that cannot be captured without reference to collective action. Those who would deny such collective responsibility commonly employ the strategy of reducing the crime of genocide to the aggregation of the actions of individuals, and especially the actions of a nation's leadership. The German nation was not guilty of genocide, but Adolf Hitler and the Nazi leadership were guilty and, for the most part, either were convicted of and punished for their crimes or died in the war; the Young Turk leadership, especially the wartime triumvirate of Talât, Enver, and Jemal Pasha, escaped judicial punishment, but "justice" was served in the case of Talât and Jemal as a result of their assassination by survivors of the Armenian genocide. ${ }^{8}$ Justice was served, so to speak, so why drag into this equation the so-called innocent, whether those who were alive at the time or those who are alive today? Shouldn't blameworthiness end with those who were "truly" responsible? My response is no; for I deny the restrictions implied by the qualification "truly," just as I would deny the blanket "innocence" of those living in communities whose leaders perpetrated genocides.

I do not want my denial to be misunderstood here, so I need to make a distinction: the distinction between law and morality. It is easy for our language to slip between the two. Legal responsibility for genocidal crimes covers the leadership and, to a certain extent, the agents who carried out that leadership's orders. But the scope of morality is not coextensive with the scope of law. Moral culpability is not the equivalent of legal culpability, and the latter should not be used to shield one from the former. Another distinction also needs to be made here, between punishment and compensation. In criminal law, wrongdoing is punished; in addition, compensation is sometimes given to the victims of such wrongdoing or to the state. Restitution of some form is made. Conceptually, one can think of these two aspects of redress as "punishment" and "repair." In the moral sphere, repair cannot simply be reduced to dollars and cents, though monetary compensation and reparations do play a significant role. Monetary repair is one component-an important component, even if only on a token basis-of the moral repair necessary for reconciliation between the survivors and the perpetrators of genocides. The fact that genocidal leaders and agents have been punished does not mean that the moral task of repair has been achieved; often this punishment is only a first small step on the road to moral repair. If punishment is used to shift moral responsibility away from the perpetrator community by limiting it to members of the leadership and their primary agents, then such punishment may hinder reconciliation. This is especially so today, when, unlike periods in the past, the institutions of international criminal law are in place to prosecute the major agents of genocide and crimes against humanity. The Nuremberg Trials were only a first step in the process of reconciliation between Jews and Germans. Justice is a necessary but not a sufficient condition for repair and reconciliation.

Now that I have dealt with the notion of causation and the strategy of denial by shifting the moral burden of responsibility to the law, I must still deal directly with the claim that one has moral responsibilities that derive not from one's own personal actions but, rather, from one's membership in a community in which historical acts of genocide occurred. While the philosophical literature on this issue is enormous and growing, the debate is relatively recent. In 1946 the German philosopher Karl Jaspers published his important study The Question of German Guilt, which explores the notion that the German people as a whole bore some moral responsibility for the 
crimes of the Nazis. ${ }^{9}$ In 1948 the English philosopher H.D. Lewis wrote a groundbreaking article in the journal Philosophy on the concept of collective responsibility. ${ }^{10}$ But it was not until the late 1970s that the philosophical literature on collective moral responsibility expanded exponentially, with contributions by philosophers too numerous to mention here. Key to this late flowering was the notion that highly organized collectives, such as corporations, could act as moral agents and could thus be said to have moral responsibilities. The work of the American philosopher Peter A. French was central to the growing recognition of concept of collective moral responsibility. ${ }^{11}$ The intricacies of these philosophical debates are not my concern here. I will argue for my position through the unusual strategy of first presenting the standard philosophical arguments against the notion that we have moral obligations that derive from the actions of our ancestors, and then taking a two-pronged approach toward refuting this argument. My first counterargument relies on the idea that moral responsibilities are conferred upon individuals on the basis of a qualified notion of ethnic identity; the second relies on the notion that maintaining the moral integrity of our social institutions requires us to assume the moral obligation of repair when such institutions have failed in the past.

To present the position against moral responsibility succinctly, I quote the American philosopher Bernard Boxill, from his article about reparations for slavery: "Since present day U.S. citizens were not complicit in the crime of slavery [the] claim [that the US government owes reparations to present-day African Americans] can only be based on the morally repugnant idea that individuals can be burdened with the duties that other people incurred." ${ }^{2}$ The assumption here is that one can be burdened with moral responsibilities only by one's own actions or by actions that one has directly authorized (i.e., the actions of one's present government). Since we are not citizens of the antebellum South, and our present government is not the same collective that existed prior to the Emancipation Proclamation, we therefore have no moral obligation to pay reparations to our African American citizens. We did not authorize our founding fathers to institutionalize slavery in our society. By extension, the post-World War II government of Germany is not the Third Reich, and the current government of the Republic of Turkey is not the Ottoman Young Turk government of World War I. Only highly organized hierarchical organizations such as business corporations can act as moral agents and thus engender moral obligations, obligations that may extend to individuals in their corporate management. The founding of the Federal Republic of Germany or the Republic of Turkey is the equivalent of the establishment of a new corporation, albeit one in which the assets of the bankrupt old regimes were assumed. These assets, it is claimed, come with no moral baggage.

I would argue, to the contrary, that this argument presents a rather weak analogy and reflects a very naïve view of history. The historical evidence for the claims in support of the argument, especially those with respect to slavery and to the Armenian Genocide, is not very strong, but to critique this evidence thoroughly would require writing another, more historically supported paper. The continuities, in terms both of personalities and ideology, between the Committee of Union and Progress (CUP, the Young Turks), who carried out the Armenian Genocide, and the founding nationalist movement of the Republic of Turkey are little acknowledged; yet these continuities contribute, in subtle and profound ways, to the inability of Turkey's current political establishment to come to terms with its past. ${ }^{13}$ On a conceptual level, what the line of reasoning outlined above fails to acknowledge is that collectivities have identities across time. A person's ethnic identity is one such identity. In more ethnically diverse 
societies, there are institutional forms of identity. The two sometimes merge. Ethnic communities are collectivities, and these collectivities frequently transcend national borders. Often ethnic conflicts that eventuate in genocides are fueled by such crossborder tensions; this was true in the former Yugoslavia, and it is certainly true in Africa, where national boundaries are artificial remnants of colonial geopolitical competition. As I remarked earlier, identities across generations result from both social institutions and cultural institutions, the chief of which are marked by ethnic group identity. The philosopher Karen Kovach has argued that while mere biological membership in one's ethnic community is not sufficient to confer collective moral obligations, if one chooses (whether explicitly or implicitly) to identify oneself with one's ethnic community, then one assumes certain moral obligations with that choice:

An ethnic identity group is a collection of individuals, each of whom may align himself with an idea of the group-where that idea is, more precisely, the idea of a collective agent, whose collectivity rests on the shared ancestry of the individuals-and each of whom may, therefore, act and respond emotionally as a member of the group. ${ }^{14}$

One's shared ancestry opens up a space in which one acts in concert, whether intentionally or not, with the "idea of the group"; one acts and responds "emotionally as a member of the group," and thus one's actions have moral implications. The particularities of this alignment can vary greatly, from the relatively trivial to the profound-from one's tastes in cuisine to one's deeply felt religious beliefs. Through such an alignment one shares in the collective agency of the ethnic group and, in so doing, shares its history of moral achievements as well as its moral failures. Again, this is not simply a matter of assuming some moral obligation because of an event in the distant past; it is part of being who you are today, whether a German, a Turk, or an American.

Moral failures and their associated obligations may be inherited, but, as in the case of a defective gene, what counts are the consequences of this inheritance. While this is not true for all genetically inherited disorders, a useful analogy is the individual who has inherited the gene for alcoholism but whose behavior is not that of an alcoholic. What I have in mind here is not blissful ignorance of one's inheritance but, rather, the constant struggle to accept one's inheritance while at the same time remodeling oneself as a sober-that is, a moral-self. The philosopher Marina A.L. Oshana, in recognizing this sense of responsibility, employs Jaspers's and Larry May's ideas of self-authenticity:

What there is to account for as well as to attribute to the agent, and to praise or blame her for, is (to borrow from Jaspers and May) authenticity with respect to one's self-conception...Authenticity consists in truthfulness toward oneself and about oneself in word and in deed. One who is authentic "meets head on his or her faults, or those of one's fellow community members, and regards oneself as at least partially responsible for them" (May 1991, 243)... Similarly, one is inauthentic when one refuses to take a stance about one's position in the world in circumstances that pressure one to do so. Inauthenticity marks a kind of dishonesty with respect to one's self-conception. ${ }^{15}$

My own concern here is with those aspects of this "idea of the group" that fueled aggression and genocidal violence in the past and that continue to be actively present in the ethnic identities of today. We have seen evidence of this in many of the ethnic conflicts that have culminated in genocides in the past 100 years, one recent example being the wars in the former Yugoslavia. A necessary condition for genuine reconciliation between the descendants of perpetrators and the descendants of their victims is sincere moral assessment, on both sides, of the alignment of oneself with 
one's ethnic identity group. This self-assessment, often aided by others, is crucial to moral authenticity. ${ }^{16}$

My second argument against those who would reject vicarious intergenerational moral responsibility based on a lack of individual culpability takes a slightly different focus. This argument is based on the following premise: the political, social, cultural, and educational institutions that mark all large collectivities such as nations provide a degree of moral reliability that is necessary for individuals to carry out their legitimate interests. We count on such institutions to exemplify the values that allow individuals to flourish in their life activities. In the words of the philosopher Janna Thompson, such collective institutions ought to value "the long-term and lifetime-transcending interests and projects" of individuals. Thompson puts it this way:

People care about how they will fare in old age, the outcome of their lifetime projects, the future well-being of their children, the fate of their community or culture, the disposal of their property, and their posthumous reputations. Their present activities, their ability to live a meaningful life, are often predicated on their ability to make plans for the more distant future, including the future beyond their lifetime, and on the presumption that institutions and practices of certain kinds will continue to exist... [They] make moral demands of citizens young and not yet born. ${ }^{17}$

If these interests are morally legitimate, then it follows that we ought to develop and maintain institutions that enable these interests to be met. There are limits to the kinds of institutions or practices I am discussing here; my claim here is restricted to what I have called "morally legitimate interests." Future generations are not obligated to maintain morally repugnant social practices and institutions (e.g., Jim Crow laws, Indian caste privileges, patriarchal inheritance rights). This is not the place to debate which interests qualify as morally legitimate, but some are fairly obvious. An institution that reliably allows one to convey one's property to one's descendants, when that property is human chattel, is not such an institution or practice; accordingly, we have no obligation to maintain or rehabilitate such institutions or practices. On the contrary, such inherited practices (e.g., slavery) obligate us to do quite the oppositethat is, to overturn them. Institutions that promote the flourishing of important life activities are by their very nature intergenerational; they do not abruptly end with a change in government, whether or not that change is politically or constitutionally legitimate. Our current government has inherited the moral obligation to provide the effective maintenance that these institutions demand. As individual citizens who are part of a collective, we have also inherited obligations under these institutions. If these institutions were perverted in the past-for example, by the US Constitution's legitimation of slavery or by the Nuremberg Laws of 1935-we have moral obligations to remedy such abuses. Repairing and making recompense for the past failures of these institutions can only serve to strengthen them in the future. Our present relationship with these institutions is what obligates us, not our complicity in some historic event in the past, be it slavery or genocide. When genocidal crimes were committed in the name of one's nation, be it Germany, Turkey, Serbia, or the United States, moral responsibility needs to be acknowledged and repair instituted. This was the path chosen in the post-World War II years by the government of Conrad Adenauer in the Federal Republic of Germany. Space does not allow me to go into the details here, but the German state's decision to pay reparations to the victims of the Nazis was the first step in reestablishing morally reliable institutions, and thus secured the trust and subsequent aid of the victorious Allied Powers. This decision solidified both the perception and the reality of Germany's commitment to democratic institutions. ${ }^{18}$ 
Unfortunately we cannot draw easy parallels between the founding of the Republic of Turkey and the post-World War II democratization of Germany. Both nations found themselves defeated and occupied by nations often in conflict among themselves. But modern Turkey was forged out of a nationalism whose ideology was developed and articulated in the same Young Turk movement that culminated in the genocide of the Armenian, Assyrian, and Pontic Greek populations of Anatolia. There is no substance to the claim by contemporary Turks that, by rejecting the national identity of Ottoman Turkey and embracing a different state form and national ethnic identity under Kemal Atatürk, they have been relieved of the obligation to repair the scars of the past. While many of the hardships and depravations of the minority populations of the Ottoman Empire can be traced to the lack of a universal form of citizenship enshrined in aspects of Ottomanism, the extermination policies of the CUP's Young Turk leadership can be traced to the pan-Turanian ideology embraced by many in this movement and carried forward in Atatürk's nationalist movement. As I stated earlier, the historical details of these connections cannot be examined in detail here. Suffice it to say that there is a growing historical literature on this issue, produced by Turkish, Armenian, and thirdparty scholars. Taner Akçam, for example, captures well the unsupportable attempt of contemporary Turks to break with their historical past:

By condemning history to obscurity, Turks are not content simply to be released of all its burdens. They believe they have created an entirely new Turkish national identity. For this purpose they erase all the unpleasant connections between the Armenian Genocide and today's Republic. Yet one of the key reasons for avoiding all discourse on the Genocide and the repression of the history of the Republic is precisely the connection between the two... My central argument is that there is a continuity of the ruling elite from the Ottoman Empire to the Turkish Republic, and so there is a strong relationship between the Armenian Genocide and the foundation of the Republic. ${ }^{19}$

Akçam goes on to document important continuities between the Armenian Genocide and the founding of the Turkish Republic. ${ }^{20}$ He argues cogently for the claim that true democratization cannot take place in Turkey without an open and frank examination of Turkish history. This is why such reforms as opening up the education system and removing legal sanctions for insulting Turkish identity need to take place before open dialogue can begin. Nearly a century ago, John Dewey identified the key role that education plays in sustaining a democratic form of life. The truism that healthy democracies are less likely to commit genocides is relevant here. ${ }^{21}$ Strengthening such institutions is the best guarantee against the recurrence of genocidal violence.

I have touched on only a few of the many issues involved in my claim that we are, in some qualified sense, morally responsible for the crimes of our ancestors. My remarks are part of a larger project, one in which I try to understand the steps necessary to achieve true reconciliation between the descendants of the victims and the descendants of the perpetrators of genocide. There is a personal dimension to this project. Ultimately, I would like to identify a path, albeit a very difficult path, to Armenian and Turkish reconciliation. I say "a difficult path" because philosophical argumentation, moral suasion, and the historical lessons of German-Jewish reconciliation are insufficient and can only provide a rough compass to guide such path-making. The Armenian Genocide is a highly controversial topic in modern-day Turkey. I have dedicated this article to the Turkish-Armenian journalist Hrant Dink, who was murdered in front of the offices of his newspaper in Istanbul for publicly speaking out on the need to acknowledge the Armenian Genocide while at the same time advocating Turkish-Armenian reconciliation and Turkey's admission into the 
European Union. This was a dangerous position to take, because the official position of the modern state of Turkey with regard to the Armenian Genocide is one of denial. ${ }^{22}$ The governments of Turkey and of its ally Azerbaijan, Turkey's semi-official organs, and many members of Turkey's political and intellectual elites are actively involved in a campaign of genocide denial. As the Holocaust scholar Deborah Lipstadt has so eloquently written, "Denial of genocide strives to reshape history in order to demonize the victims and rehabilitate the perpetrators, and is-indeed-the final stage of genocide." 23 A recognition on the part of this current generation of Turks that their historical narrative is a complex mixture of the good and the bad, and that an open discussion of this history is necessary for the moral health of their emerging democracy, is a crucial first step in bringing to an end this final stage of genocide. Whether this discussion leads, in the short term or the long term, to an official acknowledgment of the Armenian Genocide by the Turkish government is actually a secondary consideration. The acceptance of moral obligations engendered by the burden of history is a slow and tortuous process that often takes place first in civil society. There are many cases in world history of incremental progress, but they are often marked by regression-as demonstrated in the American, Canadian, and Australian acknowledgments of the crimes committed against their native populations. Even for those courageous individuals who have acknowledged such dark events in their people's collective history, the process of meeting their own moral obligations is only beginning. Acknowledgment is the first, not the final, step in moral reconciliation between the descendants of the perpetrators and the descendants of the victims of genocide.

\section{Notes}

1. Dedicated to the memory of Hrant Dink, a Turkish-Armenian journalist martyred in the cause of Armenian-Turkish reconciliation.

2. A detailed discussion of the fine points of assimilation and of ethnic, racial, or religious identity is not the focus of this essay. These identities cut across one another in myriad ways; one can lose or intentionally reject such identities, and my argument does not address such individuals. On the other hand, of course, we know that it is often not easy for victims of genocide to lose their identity, as is evident in the case of assimilated German Jews and others during the Holocaust.

3. For an extended analysis of an ethnic identity group in the context of assigning collective moral responsibility see Karen Kovach, "Genocide and the Moral Agency of Ethnic Groups," in Genocide's Aftermath: Responsibility and Repair, ed. Claudia Card and Armen T. Marsoobian, 50-70 (Oxford: Blackwell, 2007). In my analysis I have adopted Kovach's notion of ethnic identity.

4. For this article's readership I need not define the crime of genocide. Suffice it to say that I accept for my purposes the definition set out in the UN Convention on the Prevention and Punishment of the Crime of Genocide of 1948. Obviously this convention sets out only the legal parameters of the crime and does not establish conceptual boundaries or the moral ramifications of such a crime.

5. Seumas Miller, "Collective Moral Responsibility: An Individualist Account," Midwest Studies in Philosophy 30 (2006): 176-193, 178.

6. Ibid.

7. I borrow this terminology from Margaret Gilbert, "Who's to Blame? Collective Moral Responsibility and Its Implications for Group Members," Midwest Studies in Philosophy 30 (2006): 94-114.

8. On 5 July 1919, Talât and Enver Pasha, along with other members of the Committee of Union and Progress (CUP) leadership, were convicted in absentia by a special military 
tribunal set up by the successor Turkish government after the armistice that ended World War I. They had escaped punishment by fleeing to Germany after the collapse of the CUP government in October 1918.

9. Karl Jaspers, The Question of German Guilt, 2nd ed. (New York: Fordham University Press, 2001).

10. H.D. Lewis, "Collective Responsibility," Philosophy 23 (1948): 3-18.

11. Peter A. French, Collective and Corporate Responsibility (New York: Columbia University Press, 1984).

12. Bernard R. Boxill, "A Lockean Argument for Black Reparations," The Journal of Ethics 7 (2003): 63-91, 71.

13. See Taner Akçam, From Empire to Republic: Turkish Nationalism and the Armenian Genocide (London: Zed Books, 2004).

14. Kovach, "Genocide," 61.

15. Marina A.L. Oshana, "Moral Taint," in Genocide's Aftermath: Responsibility and Repair, ed. Claudia Card and Armen T. Marsoobian, 71-93 (Oxford: Blackwell, 2007), 86. The reference is to Larry May, "Metaphysical Guilt and Moral Taint," in Collective Responsibility: Five Decades of Debate in Theoretical and Applied Ethics, ed. Larry May and Stacey Hoffman, 239-54 (Savage, MD: Rowman \& Littlefield, 1991).

16. See May, ibid.

17. Janna Thompson, "Collective Responsibility for Historic Injustices," Midwest Studies in Philosophy 30 (2006): 154-67, 165.

18. See Elazar Barkan, The Guilt of Nations: Restitution and Negotiating Historical Injustices (New York: W.W. Norton, 2000), esp. 3-29.

19. Akçam, From Empire to Republic, 237-38.

20. Akçam documents three of these continuities as follows: (1) "The Turkish resistance movement in Anatolia was essentially organized by the CUP, which also organized the Genocide"; (2) many individuals who enriched themselves financially as a result of the genocide played leadership roles in the national resistance organizations (e.g., Topal Osman); (3) many key government ministers and party leaders in the Republican People's Party founded by Mustafa Kemal had been arrested and charged for their roles in the Armenian Genocide. Ibid., 238-40. See also Taner Akçam, Insan Haklari ve Ermeni Sorunu (Ankara: Imge Kitabevi, 1999).

21. This remark is not intended to get either the American republican democracy or the British parliamentary democracy off the hook for the human-rights crimes or genocides they may have committed. As a Deweyan, I am not committed to any particular set of political structures that become identified with democracies; for Dewey, democracy was a shared way of life. See John Dewey, The Public and Its Problems, in The Later Works, 1925-1953, vol. 2: 1925-1927, ed. Jo Ann Boydston (Carbondale: Southern Illinois University Press, 1984), as well as numerous other writings.

22. For a balanced treatment of the campaign of Armenian Genocide denial, see Donald Bloxham, "Epilogue: The Geopolitics of Memory," in The Great Game of Genocide: Imperialism, Nationalism, and the Destruction of the Ottoman Armenians (Oxford: Oxford University Press, 2005).

23. Deborah Lipstadt, "Armenian Genocide" (Letter), Princeton Alumni Weekly, 17 April 1996. 